\title{
Bioakumulasi Arsen (As) dan Merkuri (Hg) pada Bivalvia dari Pesisir Sekitar Demak dan Surabaya Indonesia
}

\author{
Chrisna Adhi Suryono*, Agus Sabdono dan Subagiyo
}

\author{
Departemen IImu Kelautan, Fakultas Perikanan dan IImu Kelautan, Universitas Diponegoro \\ JI. Prof Soedarto, SH. Kampus UNDIP Tembalang Semarang 50275 \\ Email: chrisna_as@yahoo.com
}

\begin{abstract}
Abstrack
The Bioaccumulation of Arsenic (As) and Mercury $(\mathrm{Hg})$ in Bivalvia from Demak and Surabaya Coastal Waters
\end{abstract}

The coastal waters at Demak and Surabaya as areas for fishing ground bivalve for consumption proposes. Unfortunately, mostly the coastal land these areas were used for industry and settlement, it will have an impact on the coastal environment. Heavy metal is one of aspect on coastal environments will give impact, especially on bivalves. This study aims to determine the metal As and $\mathrm{Hg}$ in several of bivalves tissue, seawater, sediments and bioaccumulation factors in the of Demak and Surabaya coastal waters. The analysis of As and Hg content in bivalves tissue, sediments and seawater using ICPMS. The results showed bivalves, sediments and seawater samples were found As and $\mathrm{Hg}$ concentrations. The highest concentration of As was found in the sediments; meanwhile the highest $\mathrm{Hg}$ concentration was found in the bivalve tissue of $P$. attenuatus $>$ A. pectinata $>$ A.inaequivalvis $>A$. granosa $>P$. viridis $>P$. undulada $>M$. hiantina respectively. The BAF bioaccumulation factor a significant difference $p=0.021$ and the BSAF sediment bioaccumulation factor showed a very highly significant difference $p=0.009$. The concentration of As, $\mathrm{Hg}$ and bioaccumulation factors in the two fishing ground bivalves areas shows a difference.

Keywords: Arsenic; bivalves; bioaccumulation; Mercury; sediments

\begin{abstract}
Abstrak
Pesisir sekitar Demak dan Surabaya merupakan daerah fishing ground berbagai jenis bivalvia untuk dikonsumsi. Namun sekarang pesisir daratan sebagian besar dimanfaatkan untuk industri dan pemukiman hal tersebut akan memberi dampak pada lingkungan pesisir. Logam berat merupakan salah satu aspek yang memberi dampak pada linkungan pesisir terutama pada bivalvia. Penelitian ini bertujuan mengetahui logam As dan $\mathrm{Hg}$ yang terdapat dalam jaringan beberapa jenis bivalvia, air laut, sedimen serta faktor bioakumulasi di pesisir Demak dan Surabaya. Analisa kandungan As dan Hg dalam jaringan bivalvia, sedimen dan air laut menguunakan ICPMS. Hasil penelitian menunjukan sampel bivalvia, sedimen dan air laut ditemukan As dan $\mathrm{Hg}$. Konsentrasi As tertinggi ditemukan dalam sedimen, sedangkan konsentrasi $\mathrm{Hg}$ tertinggi ditemukan dalam jaringan bivalvia secara berurutan $P$. attenuatus $>A$. pectinata $>$ A.inaequivalvis $>$ A. granosa $>P$. viridis $>P$. undulada $>T$. timorensis. Adanya perbedaan yang nyata $p=0.021$ terhadap faktor bioakumulasi BAF dan faktor bioakumulasi sedimen BSAF menunjukan perbedaan yang sangat nyata $p=0.009$. Konsentrasi As, Hg dan faktor bioakumulasi di kedua daerah fishing ground bivalvia menunjukan adanya perbedaan.
\end{abstract}

Kata Kunci : Arsen; bivalvia; bioakumulasi; Merkuri; sedimen;

\section{PENDAHULUAN}

Perairan sekitar Demak Jawa Tengah dan Surabaya Jawa Timur merupakan daerah fishing ground berbagai jenis bivalvia. Sepanjang pesisir daratan Demak sebagian besar masih digunakan sebagai lahan pertanian, pertambakan dan sebagian kecil 
pemukiman dan industri, hal tersebut sangat berbeda dengan pemanfaatan pesisir daratan Surabaya yang penggunaanya sebagian besar untuk industri, pemukiman dan sebagian kecil pertanian dan pertambakan. Namun wilalayah pesisir bagian laut di kedua wilayah memiliki fungsi yang sama yaitu sebagai daerah fishing ground bergabagai jenis bivalvia. Hal tersebut dikarenakan kedua kawasan pesisir tersebut juga dialiri bebera sungai yang membawa padatan tersuspensi maupun bahan organik dari daratan. Biasanya berbagai jenis bivalvia lebih menyukai perairan dengan tipe sedimen lumpur berpasir dan perairan tersebut terdapat muara sungai yang membawa bahan organik (Suryono et al., 2017; Suryono dan Rochaddi, 2017).

Perkebangan industri selama ini tentunya membawa konsekwensi diantaranya masuknya logam berat antropogenik ke lingkungan pesisir. Kontaminan tersebut telah menjadi perhatian karena toksisitasnya, persistennya dan kecenderungan terakumulasi dalam rantai makanan (Ansari et al., 2004; Liu et al., 2011; Liu et al., 2014). Disisi lain usaha perikanan bivalvia merupakan salah satu pendapatan utama bagi nelayan di wilayah pesisir. Namun kenyataan keselarasan antara hasil tangkapan bivalvia di laut dengan pertumbuhan industri yang memberi dampak pada lingkungan laut sulit untuk diselaraskan. Beberapa aktivitas industri dapat menyebabkan kontaminasi logam berat mercury yang siknifikan pada moluska seperti yang terjadi di Jepang, Swedia, Irak dll (Saavedra 2004; Fergusson 1990). Wilayah pesisir sering kali terkontaminasi oleh beberapa polutan yang masuk keilayah tersebut seperti logam berat, nutrien dan pestisida (Bhakta \& Munekage, 2010; ElSorogy et al., 2013). Pertambangan, peleburan logam, industri (batubara, minyak, kimia, pupuk, pestisida), rumah tangga, dan aktivitas di pelabuhan merupakan sumber logam berat antropogenik utama yang ada di wilayah pesisir (El-Sorogy et al., 2016). Polusi logam berat sudah menjadi keprihatinan di seluruh dunia karena dampaknya terhadap organisme. Deposit logam dalam sistem perairan dan bivalvia dapat terpapar dari bentuk logam yang terlarut dan partikulat (Metian et al. 2009). Logam yang terlarut dapat terakumulasi dengan cara penyerapan langsung, sedangkan logam yang berupa partikel dapat terakumulasi melalui asupan makanan yang terkontaminasi logam. Memahami cara penyerapan logam sangat penting untuk memahami bioakumulasi logam dan toksisitas. Disamping itu dapat juga untuk menetapkan kriteria kualitas air dan sedimen yang tepat. Pengetahuan tentang konsentrasi logam berat dalam jaringan biologis diperlukan, khususnya dalam fauna bentik, untuk memahami biokonsentrasi dalam jaring makanan (Cardoso et al., 2012). Studi sebelumnya menganggap fraksi terlarut sebagai kontributor utama penyerapan logam dalam invertebrata laut, tetapi bukti baru menunjukkan bahwa makanan dapat berkontribusi lebih signifikan terhadap penyerapan logam (Metian et al., 2008, 2009). Studi lain telah menyimpulkan bahwa jaringan makanan dapat menjadi penting dalam bioakumulasi beberapa logam dalam beberapa jeneis bivalvia (Metian et al. 2009) atau bahkan zooplankton (Tsui dan Wang 2004, 2007). Maka dari itu dalam penelitian ini bertujuan mengetahui logam As dan $\mathrm{Hg}$ yang terdapat dalam jaringan beberapa jenis bivalvia, air laut, sediment serta faktor bioakumulasi.

\section{MATERI DAN METODE}

Materi yang digunakan dalam penelitian ini adalah, air laut, sedimen laut dan daging bivalvia dan yang diambil dari daerah pesisir perairan sekitar Demak dan Surabaya. Sampel air laut, sedimen laut dan bivalvia diambil di daerah fishing ground kerang. Sampel sedimen diambil dengan mengunakan ekman grab, sample air laut menggunakan water bottle sampler dan sampel kerang diambil dengan menggunakan drager (garuk) (Suryono dkk, 2018a). Pengulangan pengambilan sample dilakukan sebanyak empat kali. Sampel yang diambil berupa air laut, sedimen laut dan daging bivalvia tersebut untuk diamati kandungan logam berat Arsen (As) dan Mercury ( $\mathrm{Hg})$. Analisa logam berat pada sampel mengacu (Liu et al., 2013). Sampel daging kerang dan sedimen didistruksi dengan HNO3 (Super pure, Merck, Germany) 
dalam tabung Teflon. Konsenrasi logam berat dalam air, sedimen dan daging bivalvia diukur dengan Inductively Coupled Plasma Mass Spectrometry (ICP-MS) (Elan DRC II, Perkin Elmer Company, USA). Untuk mengetahui faftor akumulasi logam dari air dan sedimen kedalam bivalvia mengacu pada bioakumulasi indek. Faktor bioakumulasi antara logam dari air ke dalam bivalvia dinyatakan sebagai (BAF) dengan perhitungan sebagai berikut $\mathrm{BAF}=\mathrm{C}_{\mathrm{LK}} / \mathrm{C}_{\mathrm{LA}}$ damana $C_{\text {LK}}$ : konsentrasi logam dalam bivalvia dan CLA: konsentrasi logam dalan air (Chevereuil et al. 1996; Suryono dkk. 2018b). Sedangkan untuk mengetahui bioakumulasi logam dari sedimen kedalam bivalvia dinyatakan sebagai (BSAF) dihitung sebagai perbadingan konsentrasi rata-rata logam dalam bivalvia terhadap konsentrasi ratarata yang terdapat dalam sedimen pada waktu tertentu. BSAF $=C_{L K} / C_{L S}$ damana $C_{L K}$ : konsentrasi logam dalam kerang dan CLS: konsentrasi logam dalan sedimen (Zhao et al. 2012; EL-Shenawy, 2016). Untuk mengetahui adanya perbedaan BAF dan BSAF antar logam dan antar lokasi dilakukan uji one-way ANOVA menggunakan MINITAB 13.3.

\section{HASIL DAN PEMBAHASAN}

Hasil penelitian terhadap bivalvia, sedimen dan air laut yang diambil pada dua lokasi yang berbeda (Demak dan Surabaya) terhadap logam As dan $\mathrm{Hg}$ menunjukan konsentrasi yang berbeda beda (Tabel 1). Dalam tabel tersebut terlihat konsentrasi logam As dan Hg dari berbagai jenis bivalvia seperti Anadara granosa, Anadara inaequivalvis, Vepricardium fimbriatum, Marcia hiantina, Perna viridis, Paphia undulate, Atrina pectinata, dan Phaxas attenuatus yang tertangkap di daerah sekitars Demak dan Surabaya. Disamping itu juga ditemukan logam As dan $\mathrm{Hg}$ dalam sedimen dan air laut di kedua daerah fishing ground bivalvia.

Logam As yang terdapat dalam sedimen dan air laut konsentarsinya lebih tinggi bila dibandingkan dengan yang terdapat dalam bivalvia di kedua daerah yang berbeda. Sebaliknya logam Hg yang terdapat dalam jaringan kerang ke kedua daerah tersebut konsentrasinya lebih tinggi bila dibandingkan dengan yang terdapat dalam sedimen dan air laut. Tingginya logam As di lingkungan merupakan hal yang logis karena logam tersebut secara alami terdapat dalam batuan. Informasi lebih lanjut mengatakan bahwa logam Arsenik tersebar di semua lingkungan, biasanya ditemukan dala jumlah kecil seperti didalam batu, tanah, air maupun jaringan organisme (Nriagu \& Pacyna, 1988). Logam tersebut berasal dari aktivitas manusia dan sumber alami yang keberadaanya tersebar luas di ekosistem perairan (Neff, 2002). Sumber polusi terbesar dari arsenik adalah bahan kimia pertanian seperti herbisida, fungisida, rodentisida dan insektisida. Masukan arsenik lokal yang paling penting ke dalam lingkungan laut dihasilkan dari peleburan logam non-ferro dan dari aliran sungai di daerah-daerah yang mengandung deposit biji besi arsenik (El-Sorogy et al., 2016).

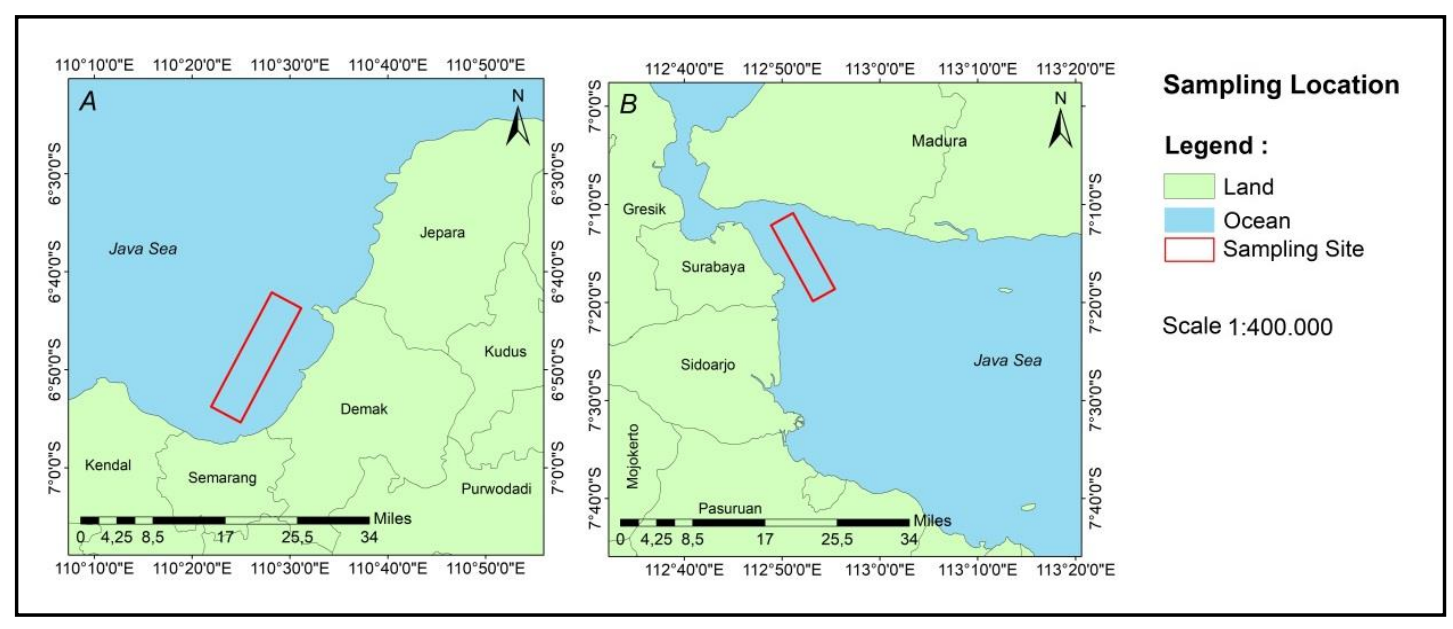

Gambar 1. Lokasi Pengambilan Sampel Bivalvia di sekitar Pesisir Demak dan Surabaya 
Maka tingginya logam As dalam sedimen dan air dapat dimengerti karena secara alami logam tersebut sudah ada dalam lingkungan dan ditambah masukan dari aktivitas manusia. Hal yang berbeda ditunjukan logam $\mathrm{Hg}$, dimanana konsentrasi yang terdapat di dalam kerang lebih tinggi bila dibandingkan dalam sedimen dan air laut di kedua daerah Demak dan Surabaya. Kondisi ini dapat dimengerti karena logam $\mathrm{Hg}$ ada dalam lingkungan laut karena adanya aktivitas manusia seperi industri, pertambangan, pertanian maupun limbah rumah tangga. Disamping itu keberadannya logam $\mathrm{Hg}$ di lingkungan laut semakin meningkat dan beracun bila siklus biogeokimianya terganggu oleh masukan antropik. Beberapa penelitian menunjukkan bahwa masukan $\mathrm{Hg}$ dari atmosfer merupakan sumber utama pencemaran merkuri dalam sistem perairan (Briant et al., 2017), dan kegiatan antropogenik terus menambahkan sejumlah besar merkuri ke udara dan akirnya turun ke liangkungan perairan (Wu et al., 2006; Chen et al., 2013). Tingkat pencemaran merkuri telah meningkat di lingkungan dan telah meningkat sebesar tiga kali lipat di permukaan laut sejak revolusi industri (Lamborg et al., 2014).

Gambar 2 menunjukan bahwa konsentrasi logam $\mathrm{Hg}$ lebih tinggi dari pada logam As dalam bivalvia di ambil di daerah Demak da Surabaya. Konsentarsi Hg tertinggi pada kerang $P$. attenuatus $>A$. pectinata $>$ A. inaequivalvis $>A$. granosa $>P$. viridis $>P$. undulada $>T$. timorensis. Dari hasil tersebut menunjukan bahwa bivalvia yang cara makanya dengan menghisap partikel dasar perairan seperti ( $P$. attenuatus, A. pectinata, A.ilnaequivalvis, A. granosa) lebih tinggi konsentarsi merkurinya dari pada bivalvia yang cara makanya menghisap air ( $P$. viridis, P. undulada, T. timorensis).

Untuk mengevaluasi besarnya bioakumulasi logam dalam bivalvia, maka faktor bioakumulasi (BAF) dan faktor bioakumulasi sedimen (BSAF) dihitung, dan hasilnya disajikan pada Gambar 3 dan 4. Nilai BAF untuk semua jenis bivalvia di kedua lokasi tertinggi adalah logam $\mathrm{Hg}$ untuk jenis A.ilnaequivalvis di kedua lokasi Demak dan Surabaya. Nilai BSAF dari semua jaringan bivalvia menunjukkan bahwa semua logam (As dan $\mathrm{Hg}$ ) yang diteliti terbioakumulasi oleh bivalvia baik yang berasal dari Demak maupun Surabaya. Nilai BSAF tertinggi pada $P$. Attenuatus yang berasal dari Surabaya dan diikuti oleh $A$. inaequivalvis yang berasal dari Demak untuk logam Hg. Hasil uji one way ANOVA terhadap faktor bioakumulasi BAF menunjukan ( $p=0.021 \leq 0.05$ ) yang menunjukan adanya perbedaan

Tabel 1. Rata rata konsentrasi \pm sd (ppm) As dan Hg pada Beberapa Jenis Bivalvia, Sedimen dan Air Laut dari Surabaya dan Demak

\begin{tabular}{lcccc}
\hline \multirow{2}{*}{ Jenis Bivalvia } & \multicolumn{2}{c}{ Surabaya } & \multicolumn{2}{c}{ Demak } \\
\cline { 2 - 5 } & As & $\mathrm{Hg}$ & As & $\mathrm{Hg}$ \\
\hline A. granosa & $0.24 \pm 0.08$ & $0.31 \pm 0.11$ & $0.29 \pm 0.06$ & $0.09 \pm 0.01$ \\
A. inaequivalvis & $0.18 \pm 0.02$ & $0.58 \pm 0.15$ & $0.20 \pm 0.05$ & $0.39 \pm 0.12$ \\
V. fimbriatum & - & - & $0.16 \pm 0.03$ & bd \\
M. hiantina & - & - & $0.23 \pm 0.03$ & $0.05 \pm 0.21$ \\
P. viridis & $0.20 \pm 0.09$ & $0.26 \pm 0.08$ & $0.09 \pm 0.01$ & $0.09 \pm 0.01$ \\
P. undulata & $0.25 \pm 0.07$ & $0.09 \pm 0.02$ & - & - \\
A. pectinata & $0.23 \pm 0.03$ & $0.66 \pm 0.21$ & - & - \\
P. attenuatus & $0.01 \pm 0.01$ & $0.80 \pm 0.09$ & - & - \\
\hline Sedimen & $0.27 \pm 0.06$ & $0.06 \pm 0.01$ & $0.16 \pm 0.02$ & $0.03 \pm 0.01$ \\
\hline Air Laut & $0.26 \pm 0.04$ & $0.13 \pm 0.01$ & $0.30 \pm 0.02$ & $0.02 \pm 0.01$ \\
\hline
\end{tabular}

Ket : $b d=$ konsentrasi sangat rendah tidak terukur oleh instrumen

- = tidak didapatkan bivalvia jenis tersebut dalam lokasi 


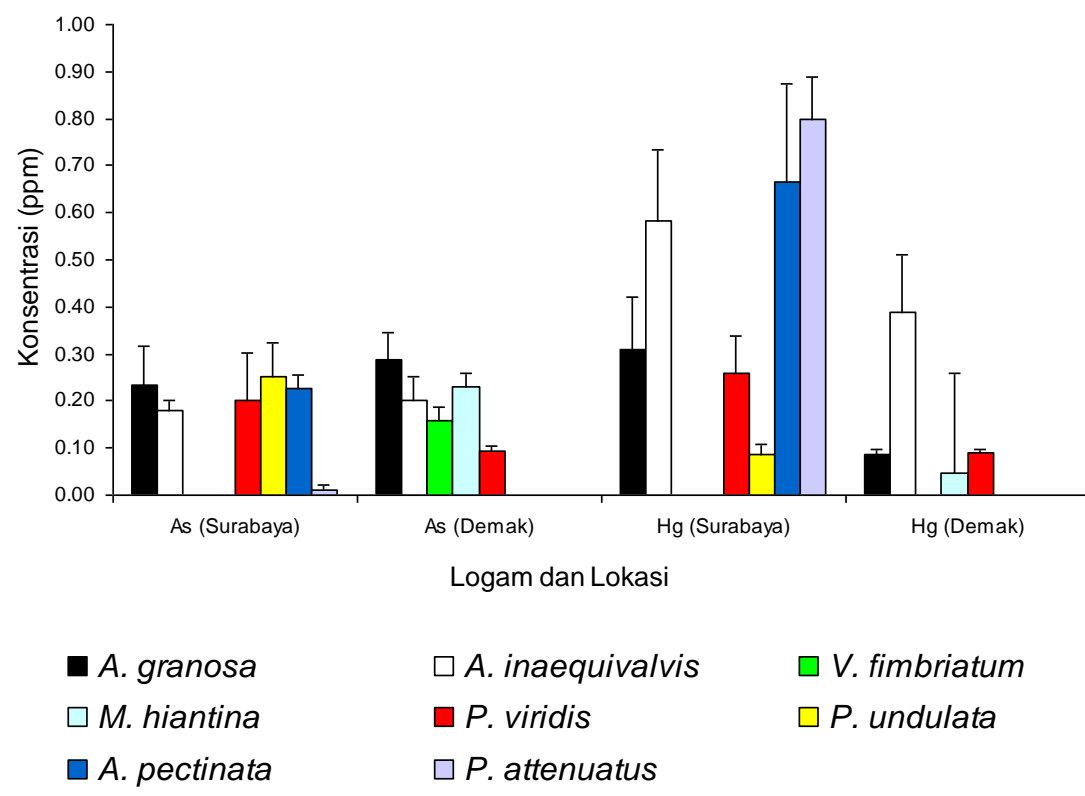

Gambar 2. Rata rata konsentrasi \pm sd (ppm) As dan Hg pada Beberapa Jenis Bivalvia, dari Surabaya dan Demak

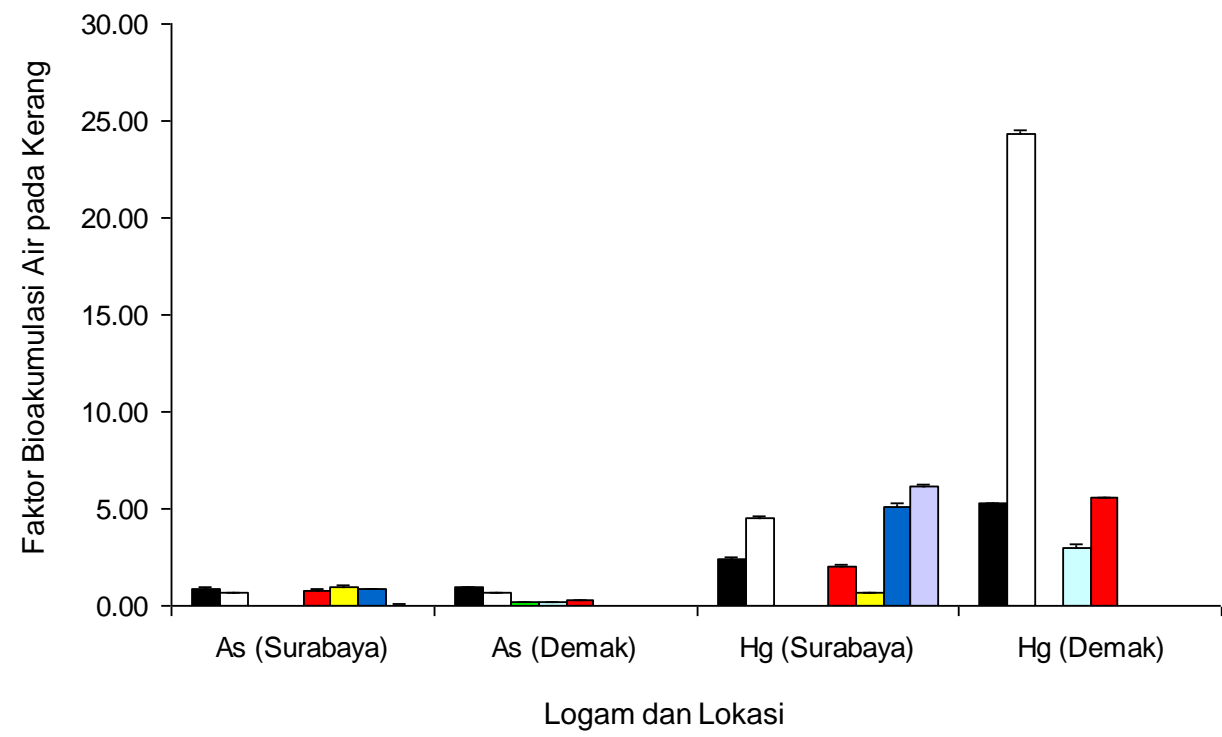
A. granosa
$\square$ A. inaequivalvis
$\square$ V. fimbriatum
$\square$ M. hiantina
$P$. viridis
$\square$ P. undulata
$\square$ A. pectinata
$\square P$. attenuatus

Gambar 3. Faktor bioakumulasi bivalvia dengan logam As dan Hg pada Beberapa Jenis Kerang, dari Surabaya dan Demak

bioakumulasi semua logam (As dan $\mathrm{Hg}$ ) pada kedua daerah. Sedangkan hasil uji one way ANOVA terhadap faktor bioakumulasi sedimen (BSAF) menunjukan ( $p=0.009 \leq 0.01$ ) menunjukan adanya perbedaan yang sangat nyata bioakumulasi sedimen semua logam (As dan $\mathrm{Hg}$ ) di kedua daerah. Keterangan diatas mengatakan bahwa bioakumulasi logam As dan $\mathrm{Hg}$ oleh beberapa jenis bivalvia disebabkan oleh 


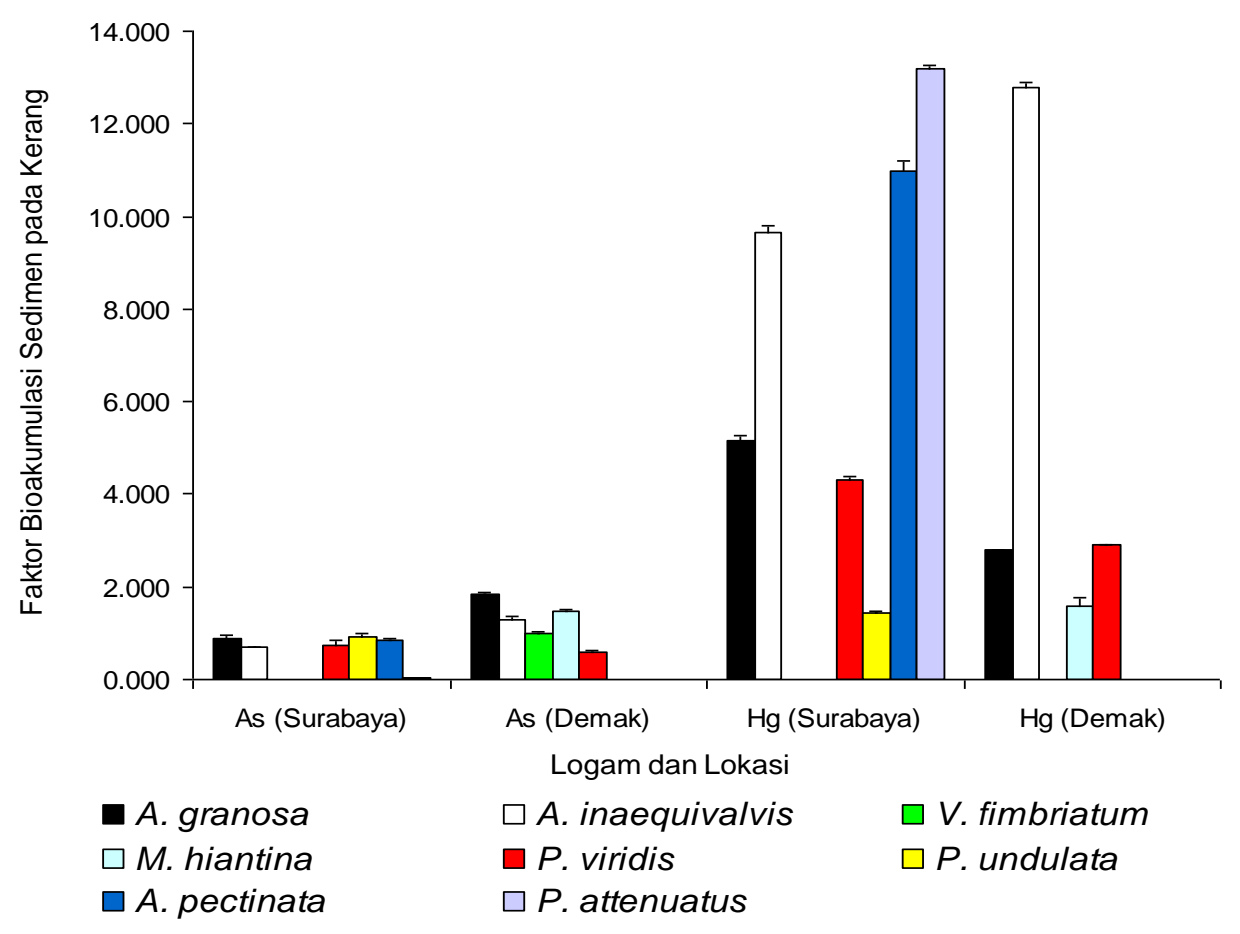

Gambar 4. Faktor bioakumulasi sedimen kerang dengan logam As dan Hg pada Beberapa Jenis Bivalvia, dari Surabaya dan Demak

faktor bioakumulasi sedimen terutama logam Hg. Hal tersebut disebabkan partikel partikel kontaminan selalu ada dalam fraksi sedimen nonresidual selalu bergerak dan cenderung masuk dalam kerang. Bivalvia adalah akumulator logam yang kuat dan dapat bertindak sebagai vektor penting untuk 'memompa' Hg ke tingkat trofik yang lebih tinggi. Penelitian sebelumnya telah menunjukkan bahwa bivalvia dapat secara efisien menyerap $\mathrm{Hg}$ dan methylmercury (MeHg) dari air dan sedimen (Pan \& Wang, 2004), dan variabel lingkungan seperti $\mathrm{pH}$, suhu, karbon organik terlarut, dan salinitas memiliki pengaruh besar pada masukmya $\mathrm{Hg}$ dalam bivalvia (Wang \& Wang, 2010; Pan \& Wang, 2011). Perbedaan konsentrasi $\mathrm{Hg}$ dalam organisme akuatik dapat mencerminkan biodinamik interspesifik $\mathrm{Hg}$, dan mungkin juga disebabkan oleh pilihan kebiasaan makan oleh organisme. Bivalvia umumnya makan dengan cara menyaring secara oportunistik seperti fitoplankton, detritus, atau alga bentik yang tersedia di habitatnya. Setiap jenis bivalvia memiliki cara makan dan sumber makan yang berbeda pula sehingga menghasilkan akumulasi logam yang berbeda pula (Rainbow, 1995).

\section{KESIMPULAN}

Kesimpulan dari penelitian ini menunjukan sampel bivalvia, sedimen dan air laut ditemukan As dan $\mathrm{Hg}$. Konsentrasi Arsen tertinggi ditemukan dalam sedimen sebesar $0.27 \pm 0.06 \mathrm{ppm}$, sedangkan konsentrasi $\mathrm{Hg}$ tertinggi ditemukan dalam jaringan bivalvia $0.80 \pm 0.09 \mathrm{ppm}$. Secara berurutan $P$. attenuatus $>$ A. pectinata $>$ A.inaequivalvis $>$ A. granosa $>P$. viridis $>P$. undulada $>T$. timorensis.

\section{UCAPAN TERIMAKASIH}

Artikel ini merupakan bagian dari penelitian Disertasi S3 program Doktor IImu Kelautan Fakultas Perikanan dan IImu Kelautan Universitas Diponegoro, Semarang.

\section{DAFTAR PUSTAKA}

Ansari, T.M., Marr, I.L. \& Tariq, N. 2004. Heavy metals in marine pollution perspective a mini review. J. App. Sci. 4:1-20 
Bhakta, J.N. \& Munekage, Y., 2010., Spatial distribution and Contamination status of Arsenic, Cadmium and Lead in some Coastal Shrimp (Macrobrachium rosenbergii) Farming ponds of Vietnam. Pacific J. Sci. Technol., 11 (1):606-615.

Briant, N., Chouvelon, T., Martinez, L., BrachPapa, C., Chiffoleau, J.F., Savoye, N., Sonke, J. \& Knoery, J., 2017., Spatial and temporal distribution of mercury and methylmercury in bivalves from the French coastline. Mar.Poll. Bull., 114:10961 102. doi:10.1016/j.marpolbul.2016.10.01 8

Cardoso, P.G., Pereira, E., Grilo, T.F., Duarte, A. C. \& Pardal, M.A., 2012., Kinetics of Mercury Bioaccumulation in the Polychaete Hediste diversicolor and in the Bivalve Scrobicularia plana, Through a Dietary Exposure Pathway. Water Air Soil Poll., 223:421-428. doi: 10.1007/s112 70-011-0870-1

Chen, L., Liu, M., Fan, R., Ma, S., Xu, Z., Ren, M. \& He, Q., 2013. Mercury speciation and emission from municipal solid waste incinerators in the Pearl River Delta, South China. Sci. Total Environ. 447:396-402.

Cheverevil, M., Blanchard, M., Teil, M. J., Carru, A. M., Testard, P., \& Chesterikoff, A., 1996., Evaluation of the pollution by organochlorine compound (Polychlorobiphenyles and pesticides) and metals $(\mathrm{Cd}, \mathrm{Cr}, \mathrm{Cu}$ and $\mathrm{Pb})$ in the water and in the zebra mussel (Dreissena polymorpha pallas) of the river Seine. Water Air Soil Poll., 88:371-381.

EL-Shenawy, N.S., Loutfy, N., Soliman, M.F.M., Tadros, M.M. \& Abd El-Azeez, A.A., 2016., Metals bioaccumulation in two edible bivalves and health risk assessment. Environ. Monit. Assess., 188(3):139 doi: 10. 1007/s10661-016-5145-2

El-Sorogy, A.S., El Kammar, A., Ziko, A., Aly, M. \& Nour, H., 2013., Gastropod shells as pollution indicators, Red Sea coast, Egypt. J. African Earth Sci., 87:93-99.

El-Sorogy, A.S., Youssef, M., Al-Kahtany,K. \& AlOtaiby, N., 2016., Assessment of arsenic in coastal sediments, seawaters and molluscs in the Tarut Island, Arabian Gulf, Saudi Arabia. J. African Earth Sci., 113: 65-72 doi: 10.1016/j.jafrearsci.2015.10.001

Fergusson, J.E., 1990., The heavy elements: chemistry, environmental impact and health effects. Part IV. The toxicity of heavy elements to human beings. Pergamon, New York, pp 533-567

Lamborg, C.H., Hammerschmidt, C.R., Bowman, K.L., Swarr, G.J., Munson, K.M., Ohnemus, D.C., Lam, P.J., Heimbürger, L.E., Rijkenberg, M.J.A., \& Saito, M.A., 2014., A global ocean inventory of anthropogenic mercury based on water column measurements. Nature, 512 (7512):65-68. doi: 10.1038/nature13563

Liu, G.X., Chai, X.L., Shao, Y.Q., Hu, L.H., Xie, Q.L., \& WU, H.X., 2011 ., Toxicity of copper, lead and cadmium on motility of two marine microalgae Isochrysis galbana and Tetraselmis chui. J. Environ. Sci., 23:330-335

Liu, G.X., Shu, M. A., Chai, X. L., Shao, Y.Q., Wu, H.X., Sun, C.S., $\$ \& Yang, S.B., 2014. Effect of Chronic Sublethal Exposure of Major Heavy Metals on Filtration Rate, Sex Ratio, and Gonad Development of a Bivalve Species. Bull. Environ. Contaminat. Toxicolog. 92:71-74. doi: 10.1007/s00128-013-1138-9

Liu, J.H., Cao, L., Huang, W. \& Dou, S.Z., 2013. Species- and tissue-specific mercury bioaccumulation in five fish species from Laizhou Bay in the Bohai Sea of China. Chin. J. Oceano. Limnol., 31:504-513

Metian, M., Bustamante, P., Hédouin, L., Oberhänsli, F. \& Warnau, M., 2009., Delineation of heavy metal uptake pathways (seawater and food) in the variegated scallop Chlamys varia, using radiotracer techniques. Mar. Ecol. Prog. Ser., 375:161-171.

Metian, M., Warnau, M., Cosson, R. P., Oberhänsli, F. \& Bustamante, P. 2008., Bioaccumulation and detoxification processes of $\mathrm{Hg}$ in the king scallop Pecten maximus: field and laboratory investigations. Aqua. Toxicol., 90:204-213

Neff, J.M., 2002., Arsenic in the ocean. In: Bioaccumulation in Marine Organisms Effect of Contaminants from Oil Well Produced Water. Elsevier Science, Oxford, pp. 57-78.

Nriagu, J.O. \& Pacyna, J.M., 1988. Quantitative assessment of worldwide contamination of air, water and soil by trace metals. Nature 333:134-139

Pan, J.F. \& Wang, W.X., 2004. Uptake of Hg(II) and methylmercury by the green mussel Perna viridis under different organic 
carbon conditions. Mar. Ecolog. Prog. Ser. 276:125e136

Pan, J.F. \& Wang, W.X., 2011. Mercury accumulation in marine bivalves: Influences of biodynamics and feeding niche. Environ. Poll. 159: 2500-2506 doi: 10.1016/j.envpol.2011.06.029

Rainbow, P.S., 1995. Biomonitoring of heavy metal availability in the marine environment. Marine Pollution Bulletin 31: 183-192.

Saavedra, Y., Gonzalez, A., Fernandez, P. \& Blanco, J. 2004., Interspecific Variation of Metal Concentrations in Three Bivalve Mollusks from Galicia. Arc. Environ. Contaminat. Toxicolog. 47:341-351 doi 10.1007/s00 244-004-3021-5

Suryono, C.A., Susilo, E.S., Arinianzah, A.D., Setyati, W.A. Irwani \& Suryono., 2018b., Kontaminasi tembaga pada Mugil dussumieri (Actinopterygii: Mugilidae, Forsskal, 1775) yang ditangkap di perairan Semarang, Indonesia. J. Kel. Trop., $21(2): 91-96$. doi : 14710/jkt.v21i1. 2402

Suryono, C.A., \& Rochaddi, B., 2017., Kualitas perairan di daerah fishing ground nelayan kerang di pesisir timur Kota Semarang. J. Kel. Trop., 20(1): 42-47

Suryono, C.A., Riniatsih, I., Nuraini, R.A.T., Djunaedi, A., Rochaddi, B. \& Subagiyo., 2017. Ekologi perairan SemarangDemak: Inventarisasi jenis kerang yang ditemukan di dasar perairan. J. Kel. Trop., 20(2):84-89
Suryono, C.A., Widada, S., Rochadi, B., Subagiyo., Setyati, W.A. \& Susilo, E.S., 2018a. Kontaminasi Logam Berat Arsen (As), Mercury ( $\mathrm{Hg})$ dan Magnesium (Mg) pada Air Laut Sedimen dan Kerang bulu Anadara inaequivalvis (Mollusca: Bivalvia, Bruguiera, 1792) di Perairan Brebes Jawa Tengah Indonesia. J. Kel. Trop., 21 (2):150-154. doi: 10.14710/jkt.v2 1 i2.3850

Tsui, M. T. K. \& Wang, W.X., 2004., Uptake and elimination routes of inorganic mercury and methylmercury in Daphnia magna. Environ.I Sci. Technol., 38:808-816.

Tsui, M. T. K., \& Wang, W.X., 2007., Biokinetics and tolerance development of toxic metals in Daphnia magna. Environ. Toxicolog. Chem., 26:1023-1032.

Wang, R., \& Wang, W.X., 2010. Importance of speciation in understanding mercury bioaccumulation in tilapia controlled by salinity and dissolved organic matter. Environ. Sci. Technol., 44:7964-7969.

Wu, Y., Wang, S., Streets, D.G., Hao, J., Chan, M., \& Jiang, J., 2006. Trends in anthropogenic mercury emissions in China from 1995 to 2003. Environ. Sci. Technol., 40(17):5312-5318.

Zhao, L., Yang, F., Yan, X., Huo, Z. \& Zhang, G., 2012. Heavy metal concentrations in surface sediments and manila clams (Ruditapes philippinarum) from the Dalian coast, China after the Dalian Port oil spill. Biol. Trace Element Res., 149:241247. 